Research Papers, part of a Special Feature on Conservation of Grassland Birds: Causes and Consequences of Population Declines

\title{
An Assessment of Factors Affecting Population Growth of the Mountain Plover
}

\section{Évaluation des facteurs influençant la croissance de la population du Pluvier montagnard}

\author{
$\underline{\text { Stephen J. Dinsmore }}^{1}$, Michael B. Wunder ${ }^{2}$, Victoria J. Dreitz ${ }^{3}$, and Fritz L. Knopf ${ }^{4}$
}

\begin{abstract}
Effective conservation measures should target the most sensitive life history attributes of a species, assuming they are responsive to potential management actions. The Mountain Plover (Charadrius montanus) is a species of conservation concern with a patchy breeding distribution in western North America. Plovers prefer areas with short vegetation, bare ground, and disturbance for nesting. Current management tools, including grazing and burning, have been used to attract plovers and enhance nesting success. We used a stage-specific matrix model to study the influence of vital rates, e.g., juvenile and adult annual survival, on population growth rate in the Mountain Plover at two breeding sites in Colorado, South Park and Eastern Colorado, and one breeding site in Montana, USA. Our analysis was motivated by a need to 1) better understand the relationship between demographic rates and population growth rate, 2) assess current management tools for the plover by exploring their effect on population growth rate, and 3) identify areas of the plover's population biology where additional demographic work is needed. Stochastic population growth rate was most influenced by adult survival, especially in Montana and South Park, Colorado (elasticities $>0.60$ ), and was least influenced by first-year reproduction (all elasticities $<0.20$ ). The modeled relationships between lambda and each demographic rate were generally weak $\left(\mathrm{r}^{2}<0.30\right)$ with the exception of number of eggs hatched per nest in Eastern Colorado $\left(r^{2}=0.63\right)$, chick survival in South Park $\left(r^{2}=0.40\right)$ and Montana $\left(r^{2}=0.38\right)$, and adult survival in Montana $\left(r^{2}=0.36\right)$. We examined the predicted increase in lambda that would result from increasing each demographic rate from its mean to the maximum value observed in our simulations. Chick and adult survival showed the greatest increase in lambda while eggs hatched per nest produced the smallest increase. Our results suggest that future conservation efforts should favor ways to increase adult or chick survival over efforts to increase nest success. In particular, adult survival rates during the stationary periods, i.e., summer and winter, are relatively high, implying that efforts to increase adult survival rates may need to focus on the migratory periods. Increasing chick survival should be a priority for efforts that are restricted to the breeding grounds because this life history stage is relatively short $(<3 \mathrm{mo})$ and it offers opportunities for targeted short-term management activities in breeding areas.
\end{abstract}

RÉSUMÉ. Pour être efficaces, les mesures de conservation devraient cibler les éléments les plus sensibles du cycle biologique d'une espèce, en supposant que les actions de gestion possibles peuvent avoir un effet sur eux. Le Pluvier montagnard (Charadrius montanus), espèce dont le statut est préoccupant, présente une aire de reproduction clairsemée dans l'ouest de l'Amérique du Nord. Ce pluvier préfère nicher dans les endroits pourvus de végétation courte et de sol à nu, et qui sont fréquemment perturbés. Le pâturage et le brûlage, deux outils actuels de gestion, ont été utilisés pour attirer les pluviers et améliorer leur succès de

${ }^{1}$ Iowa State University, ${ }^{2}$ Colorado State University, ${ }^{3}$ Colorado Division of Wildlife, ${ }^{4}$ U. S. Department of Interior (Retired)

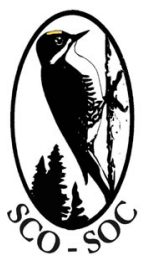

Sponsored by the Society of Canadian Ornithologists and Bird Studies Canada Parrainée par la Société des ornithologistes du Canada et Études d'oiseaux Canada

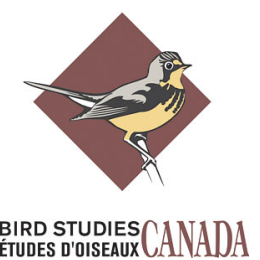


nidification. Nous avons utilisé un modèle matriciel spécifique au stade afin d'évaluer l'influence des taux vitaux, par exemple le taux de survie des jeunes et des adultes, sur le taux de croissance de la population du Pluvier montagnard, à deux sites de nidification au Colorado (South Park et l'est du Colorado) et un site au Montana, aux États-Unis. Les objectifs de notre analyse étaient de : 1) mieux comprendre la relation entre les taux démographiques et le taux de croissance des populations; 2) évaluer les outils actuels de gestion destinés au pluvier en explorant leur effet sur le taux de croissance de la population; 3) déterminer quels aspects de la biologie des populations du pluvier nécessitent davantage de travaux sur la démographie. Le taux de croissance stochastique de la population a été fortement influencé par la survie des adultes, particulièrement au Montana et à South Park au Colorado (élasticité >0,60), et peu par la reproduction à la première année (toutes les élasticités < 0,20). Les relations modélisées entre lambda et chaque taux démographique étaient faibles en général $\left(\mathrm{r}^{2}<0,30\right)$, sauf en ce qui concerne le nombre d'œufs éclos par nid dans l'est du Colorado $\left(\mathrm{r}^{2}=0,63\right)$, la survie des poussins à South Park $\left(\mathrm{r}^{2}=0,40\right)$ et au Montana $\left(\mathrm{r}^{2}=\right.$ $0,38)$, et la survie des adultes au Montana $\left(\mathrm{r}^{2}=0,36\right)$. Nous avons examiné l'augmentation prévue de lambda qui résulterait de l'augmentation de chaque taux démographique de sa valeur moyenne à sa valeur maximale observée dans nos simulations. La hausse de la survie des poussins et des adultes a mené à l'augmentation la plus grande de lambda, tandis que la hausse du nombre d'œufs éclos par nid a produit l'augmentation la plus faible de lambda. Nos résultats semblent indiquer que les futures mesures de conservation devraient viser l'augmentation de la survie des adultes ou des poussins plutôt que l'augmentation du succès de nidification. Plus précisément, les taux de survie des adultes durant les périodes stationnaires, c.-à-d. l'été et l'hiver, sont relativement élevés, de sorte que les mesures visant l'augmentation de la survie des adultes devraient peut-être être appliquées durant les périodes de migration. L'augmentation de la survie des poussins devrait être une priorité d'action sur les aires de reproduction, parce que ce stade du cycle biologique est relativement court ( $<3$ mois) et qu'il offre des occasions de réaliser des actions ciblées de gestion à court terme sur les aires de reproduction

Key Words: Charadrius montanus; elasticity; Mountain Plover; population growth; sensitivity; trend

\section{INTRODUCTION}

The Mountain Plover (Charadrius montanus) has received substantial conservation attention (Brown et al. 2001) because of its localized breeding distribution (Knopf and Wunder 2006), perceived long-term population declines (U. S. Department of Interior 2003), and recognition as an indicator species of the Great Plains ecosystem (see Knopf and Samson 1997). An earlier attempt to understand basic population processes in the plover (Dinsmore 2003) showed that population growth rate was strongly influenced by adult and chick survival. However, that exercise was restricted to a portion of their range, Montana, and included untested assumptions about key parameters; a more thorough investigation of this topic is needed. In the last decade, several conservation measures have been enacted to benefit the plover including prescribed burning to benefit nesting plovers (U. S. Forest Service 2002), the establishment of an Area of Critical Environmental Concern (ACEC) for the plover in Montana (U. S. Department of Interior 2000), the designation of Important Bird Areas in California, Montana, Wyoming, Colorado, and New Mexico by the National Audubon Society, and a landowner incentive program to protect nests in Colorado and Nebraska (Kerns and Hanni 2006, Lock and VerCauteren 2008). Collectively, these management tools strongly favor strategies to increase nest survival over strategies that address other aspects of the plover's life history. Such strategies often focus on the nest stage because nests are immobile, relatively easy to locate and monitor, can be more easily protected than mobile chicks, and success can be documented in elevated levels of nesting success. However, no empirically-based research has determined that nest survival is directly responsible for the plover's decline (Dinsmore 2003). Thus, the present management approach for the plover is to enhance nesting success in the face of evidence that suggests this is not the life-history strategy that should be targeted. 
A common goal in studies of threatened animal populations is to understand future population risk as a function of various life-history based demographic rates, i.e., vital rates (Caswell 2001, Williams et al. 2001). Animal populations fluctuate through time as a result of gains, i.e., births and immigration, and losses, i.e., deaths and emigration, and an understanding of these temporal patterns is needed for conservation efforts. Many analytical tools, each requiring demographic data collected from field studies and a basic understanding of the species' annual cycle, can be used to address this problem. Some popular tools to assess the health of a population include projecting future population growth rate $(\lambda)$ with the use of matrix models, conducting population viability analyses (PVA), and examining the elasticity or sensitivity of parameters to overall population growth (Morris and Doak 2002). A detailed analysis can also quantify the sensitivity or elasticity of population growth rate to components of the matrix model, providing further insight into population processes (Caswell 2001). Collectively, these and other analyses offer a means of better understanding the interactions between population growth rate and its components. A simplistic population model was previously developed for the Mountain Plover (Dinsmore 2003); more comprehensive models were completed for the Piping Plover (Charadrius melodus; Calvert et al. 2006), a related species, and for the European Oystercatcher (Haematopus ostralegus; GossCustard et al. 1995a,b). Understanding relationships between population growth and specific life history parameters is important and can often provide valuable insight into key management concerns.

Our goal was to synthesize the most current information about the Mountain Plover into a population model to assess the effect of life history parameters on population growth rate and evaluate current management approaches for this species. The current analysis builds on the earlier modeling exercise of Dinsmore (2003) by including information from three widely separated breeding areas to provide spatial replication that is more representative of the species' current breeding range. Specifically, we wanted to address three questions: (1) How do specific life history parameters influence plover population growth at three principle breeding sites?; (2) What are the potential benefits of current management actions for the plover?; and (3) Are there aspects of its life history where future research efforts and management actions should be directed? Although we report estimates of population growth rate in this paper, our focus is on the factors that affect population growth rather than the rate per se.

\section{METHODS}

\section{Study areas}

Our work with the Mountain Plover spanned much of the species' primary breeding range in North America. The data used herein come from long-term studies of the plover at three sites. From 1991-2007 we worked in southern Phillips County, Montana, hereafter Montana (Dinsmore et al. 2002, Dinsmore et al. 2003, Dinsmore et al. 2005, Dinsmore and Knopf 2005, Dinsmore 2008) near the northern limit of the species' range, an area of mixed mid-grass prairie where most plovers occur on black-tailed prairie dog (Cynomys ludovicianus) colonies. From 1990-2006 we worked at several locales on the plains of eastern Colorado, hereafter E Colorado (Knopf and Rupert 1996, Dreitz 2005, Dreitz et al. 2005), a region of short-grass prairie, agricultural lands, and black-tailed prairie dog colonies that is often considered the core of the species' breeding range. From 1995-2005 we worked in the South Park region of Colorado, hereafter South Park, which is a high elevation short-grass prairie that historically was grazed by bison and Gunnison's prairie dog (Cynomys gunnisoni), and that is now grazed primarily by domestic bison and cattle (Wunder et al. 2003).

\section{Mountain Plover ecology}

The Mountain Plover is a medium-sized $(\sim 100 \mathrm{~g})$ migratory shorebird that nests at disturbed sites with short vegetation along the western edge of the Great Plains and into adjacent xeric shrub-steppe habitats. Plovers migrate to desert and agricultural regions from south Texas west across Mexico and north into the Imperial and San Joaquin Valleys of California (Knopf and Wunder 2006). Most demographic estimates are derived from studies of the breeding biology, but some within-season survival rates during winter have been estimated (Knopf and Rupert 1995). There are no empirical estimates for survival rates during spring and fall migration periods. 
Plovers have a rapid multiclutch mating system (Graul 1973) whereby each member of a pair tends a separate nest and raises the offspring alone. Single nests typically hold three eggs, with a range of one to six eggs (Knopf and Wunder 2006). Plovers first breed at age 1 and probably nest annually thereafter (Dinsmore 2001). This strategy results in an average clutch of six eggs per year, split between two different nests. The species is long-lived and individuals in Montana have lived $>10$ years (S. J. Dinsmore, personal observation). The Mountain Plover has been a focal study species on the Great Plains and we have detailed information on nest survival at each site (e.g., Knopf and Rupert 1996, Dinsmore et al. 2002, Dreitz and Knopf 2007), chick survival at two of the sites, Montana and E Colorado (Dinsmore and Knopf 2005, Dreitz 2009), and agespecific annual survival in Montana (Dinsmore et al. 2003, Dinsmore 2008). This information forms the basis for our population model.

\section{Model development}

Our population model for the Mountain Plover assumes a life cycle with two stages, juveniles and adults. From this we developed a matrix model with a post-breeding census for a birth-pulse population with a one-year census interval (McDonald and Caswell 1993, Caswell 2001). Our two-stage matrix population model included stochasticity in parameter estimates so we could further evaluate factors influencing population growth rate $(\lambda)$. To add spatial replication our model included three geographically distinct populations, one each with characteristics from Montana, EColorado, and South Park. We did not model interactions between these sites, e.g., emigration and immigration rates, because a) this has not been documented from color-banded plovers, and b) this level of complexity was not a focus of our analyses.

Vital rates included in our analyses were calculated from several sources. Nest survival was estimated in program MARK (White and Burnham 1999) using the nest survival model (Dinsmore et al. 2002) for each site to correct for the bias associated with traditional Mayfield approaches (Mayfield 1961, 1975). For chick survival in Montana we used a Kaplan-Meier model in MARK that allowed exact failure dates to be unknown, tested for model fit using a chi-square test, and obtained a variance inflation factor $(\hat{c})$ that was adjusted in MARK (Dinsmore and Knopf 2005). For chick survival in Eastern Colorado we used an analytical approach that requires the attending adult to be uniquely marked, e.g., radio transmittered, and the dependent young are not required to be uniquely marked (Lukacs et al. 2004, Dreitz 2009). Estimates of juvenile and adult survival came only from Montana and were calculated using a robust design model (Pollock 1982, Kendall et al. 1995) in program MARK; model fit could not be assessed (Dinsmore 2008). In addition to these rates, we included the normal range in clutch size observed in this species, zero to three eggs, and calculated the probability that an individual egg would hatch from site-specific nest monitoring data.

We used estimates of the six vital rates described above to parameterize the elements of our matrix model. These vital rates included four sequential survival rates as follows. Nest survival $\left(S_{\text {Nest }}\right)$ was the probability that $\geq 1$ egg hatched in a nest. After hatch, chick survival $\left(S_{\text {Chick }}\right)$ refers to the 35-day interval from hatch to fledging, juvenile survival $\left(S_{\text {Juvenile }}\right)$ refers to the interval from fledging to first birthday (age 1$)$, and adult survival $\left(S_{\text {Adult }}\right)$ refers to the probability of surviving each subsequent year. We calculated each of the matrix elements as follows: $f_{1}=S_{0} * E g g s ; f_{2}=S_{1} * E g g s, S_{0}=S_{\text {Chick }} *$ $S_{\text {Juvenile }}$; and $S_{1}=S_{\text {Adult }}$. The value for Eggs was Eggs $=S_{\text {Nest }} *$ number of eggs hatched. The number of eggs hatched was distributed as a binomial with success parameter estimated as the probability that an individual egg hatches $\left(P_{\text {Hatch }}\right)$. We made the following distributional assumptions about each parameter in our model:

$S_{\text {Chick }} \sim \operatorname{Beta}\left(\alpha_{\text {Chick }}, \beta_{\text {Chick }}\right)$,

$S_{\text {Juvenile }} \sim \operatorname{Beta}\left(\alpha_{\text {Juvenile }}, \beta_{\text {Juvenile }}\right)$,

$S_{\text {Adult }} \sim \operatorname{Beta}\left(\alpha_{\text {Adult }}, \beta_{\text {Adult }}\right)$,

$S_{\text {Nest }} \sim \operatorname{Beta}\left(\alpha_{\text {Nest }}, \beta_{\text {Nest }}\right)$,

Number of eggs hatched $\sim$ Binomial $\left(3, P_{\text {Hatch }}\right)$, and $P_{\text {Hatch }} \sim \operatorname{Beta}\left(\alpha_{\text {Hatch }}, \beta_{\text {Hatch }}\right)$.

We used method of moments to parameterize the above distributions from site-specific parameter estimates $( \pm$ SE) obtained from our studies of the Mountain Plover (Table 1). The method of moments is a way to estimate population parameters, e.g., mean and variance, by equating sample moments with unobserved population moments and then solving the equation for the unknown parameter. 
Table 1. Parameter estimates (SE) used to model the elasticity of stochastic population growth $(\lambda)$ for Mountain Plovers breeding in Montana, eastern Colorado, and the South Park region of Colorado.

\begin{tabular}{lccc}
\hline \hline Parameter & Montana & E Colorado & South Park \\
\hline${ }^{\dagger}$ Eggs per clutch & 0 to 3 & 0 to 3 & 0 to 3 \\
$P_{\text {Hatch }}$ & $0.91(0.11)$ & $0.92(0.08)$ & $0.90(0.12)$ \\
${ }^{\ddagger} S_{\text {Nest }}$ & $0.46(0.06)$ & $0.35(0.01)$ & $0.63(0.16)$ \\
${ }^{8} S_{\text {Chick }}$ & $0.19(0.06)$ & $0.67(0.01)$ & $0.19(0.06)$ \\
${ }^{\mid} S_{\text {Juvenile }}$ & $0.62(0.03)$ & $0.62(0.03)$ & $0.62(0.03)$ \\
$\mid S_{\text {Adult }}$ & $0.87(0.05)$ & $0.87(0.05)$ & $0.87(0.05)$ \\
\hline
\end{tabular}

†We assumed that the number of successful eggs per clutch ranged from 0 to 3 , although nests rarely contain up to 6 eggs.

*Nest success was estimated using nest survival models (Dinsmore et al. 2002) that correct for the bias in traditional Mayfield estimates.

$\S$ The chick survival estimate for Montana was used for South Park.

Juvenile and adult survival were estimated only in Montana, but were used for the other 2 sites.

We did not model any changes in fertility with age because of a lack of data, although this assumption is often justified in studies of avian demography (Ricklefs 1973, McDonald and Caswell 1993). We assumed that plovers attempt to breed starting the year after their first winter (Skrade and Dinsmore 2010) and that all birds attempt to breed every year, which was confirmed with color-banded birds in Montana. We assumed a 1:1 sex ratio and modeled both sexes because of the unique way in which nest tending is shared. Survival rates are not known to be meaningfully different between the sexes (Dinsmore et al. 2003, Dinsmore 2008). We did not attempt to separate process and sampling error in estimates of vital rates, so the variances on these parameters reflect total error (Link and Nichols 1994). Lastly, we make the implicit assumption that each population is at a stable age distribution, which is best supported in Montana (Dinsmore et al. 2005) and assumed anecdotally at the two Colorado sites.

We iterated 10,000 simulations in MatLab (The MathWorks Inc., Natick, MA, USA) for each population using site-specific parameter estimates.
We calculated Tuljapurkar's approximation for stochastic lambda (Tuljapurkar 1982, Caswell 2001 [Equation 14.72]) and its elasticity to (1) the mean of the elements of the matrix, (2) the variance of those matrix elements, and (3) the covariance of the matrix elements. Stochastic lambda, also called the stochastic population growth rate, is a measure of the mean change in population growth and its variance. Elasticities are the sensitivities of lambda to proportional changes in vital rates and thus partly avoid the problem of differences in units of measurement (Caswell 2001). Unit of measurement was a factor in our analysis because parameter estimates were continuous in the range [0,1], except that the number of eggs per clutch was an integer in the range $[0,3]$. The elasticities also have the useful property of summing to 1 . The interpretation of elasticities to proportional changes to the mean of the matrix elements is straightforward. We also included analyses of the elasticities to the variance and covariance of the set of simulated values for the matrix elements as a means of checking the interpretation of results with the addition of stochasticity in parameter estimates. 
Table 2. Site-specific estimates of Tuljapurkar's approximation for stochastic lambda $(\lambda)$ and the elasticity of population growth to each of the four matrix elements for Mountain Plovers breeding in Montana, eastern Colorado, and the South Park region of Colorado. The matrix elements are first-year reproduction $\left(f_{1}\right)$, afterfirst-year reproduction $\left(f_{2}\right)$, first-year survival $\left(S_{0}\right)$, and after-first-year survival $\left(S_{1}\right)$.

\begin{tabular}{lccccc}
\hline \hline Site & $f_{1}$ & $f_{2}$ & $S_{0}$ & $S_{1}$ & $\lambda$ \\
\hline Montana & 0.0453 & 0.1395 & 0.1398 & 0.6828 & 1.0473 \\
E Colorado & 0.1984 & 0.2180 & 0.2159 & 0.3722 & 1.3766 \\
South Park & 0.0753 & 0.1684 & 0.1673 & 0.6015 & 1.1112 \\
\hline
\end{tabular}

We further explored the influence of individual vital rates on population growth rate at each site in three ways. First, we used the mean values of each vital rate at each site, calculated from the simulation exercise, to estimate lambda and its elasticity to the mean values of the vital rates. Second, we examined the distribution of each vital rate from the simulation exercise and determined its maximum value at each site. We then calculated lambda at this maximum value $\left(\lambda_{\text {Max }}\right)$ for each site, holding all other vital rates at their mean. We used this result and the value of lambda at the mean of each vital rate $\left(\lambda_{\text {Mean }}\right)$ to calculate the increase in lambda as $\Delta \lambda=\lambda_{\text {Max }}-\lambda_{\text {Mean }}$ for each site. We did this singly for each vital rate as a means of assessing potential population gain that could result when a single vital rate was increased from its mean to its maximum value. Third, we calculated the coefficient of determination $\left(r^{2}\right)$ from linear regressions of the distributions of the vital rates and the lambdas from the simulations at each site to better understand how uncertainty in each vital rate related to population growth rate.

\section{RESULTS}

The majority of simulations resulted in values of $\lambda>1$ for all sites (Fig. 1). Stochastic model results provided detailed insight into the influence of various vital rates on population growth rate in the Mountain Plover. For most analyses, we found similar patterns for Montana and South Park; results for E Colorado often differed substantially. At each site, stochastic population growth was influenced most by proportional changes in mean adult survival and least by those for first-year reproduction (Table 2 ). Elasticities for adult survival were $>0.60$ for Montana and South Park and 0.37 for E Colorado (Table 2). Conversely, elasticities were low $(<0.20)$ for first-year reproduction at all sites. Estimates of stochastic population growth rate using the means of site-specific parameter estimates were $>1$ for all sites (Table 2). Elasticities to the variance and covariance of the simulated matrix elements confirmed the patterns we saw using only the means of the matrix elements.

At each site, estimates of stochastic lambda were almost identical to estimates of lambda generated using the mean value of each vital rate (Table 3 ). When we examined the influence of variance in individual vital rates on variation in population growth rate, we found that relationships to lambda were generally weak $\left(r^{2}<0.30\right)$ for most vital rates, indicating imprecise knowledge of parameter values, model structure, or both (Table 4). The exceptions were eggs/nest in E Colorado $\left(r^{2}=0.44\right)$, and chick survival in South Park $\left(r^{2}=0.37\right)$ and Montana $\left(r^{2}=0.42\right)$. The increase in asymptotic population growth rate $(\lambda)$ that resulted when maximum values for each set of simulated vital rates were substituted for mean values (Fig. 1) suggests the importance of each vital rate to potential population growth. Predicted changes in lambda were similar for Montana and South Park. Maximizing chick survival for these two sites resulted in the greatest overall proportional increase in any vital rate, 1.63 and 1.51 respectively, and also yielded the largest net increase in lambda. Maximizing juvenile survival or eggs/nest produced 
Fig. 1. Distribution of per-simulation lambda for Mountain Plovers breeding in Montana, eastern Colorado, and the South Park region of Colorado.
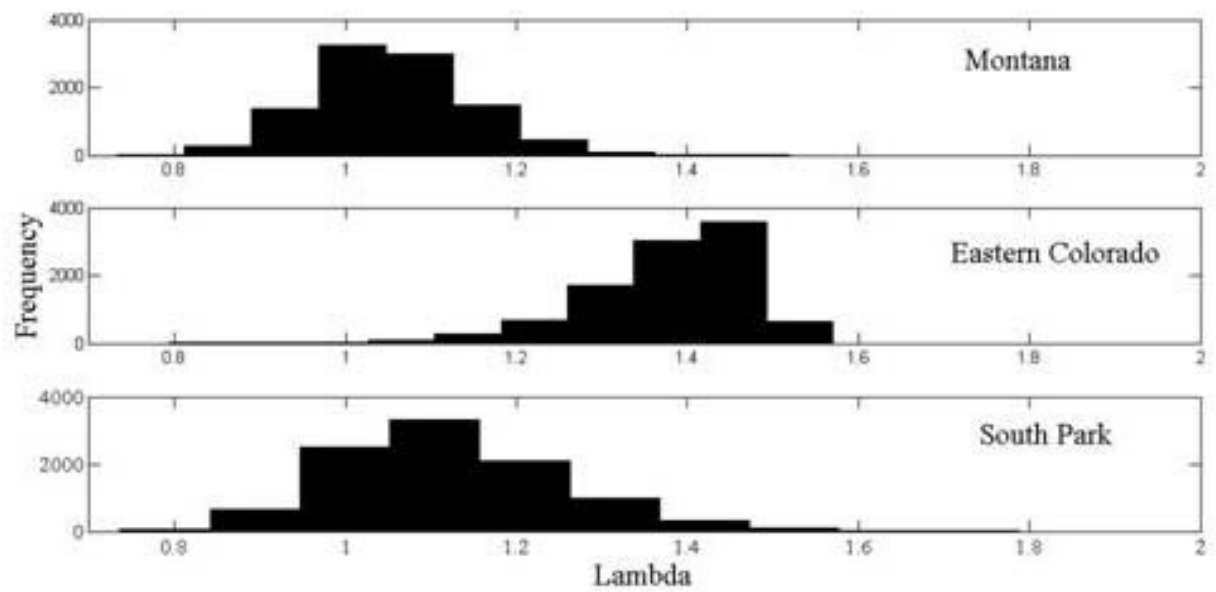

the smallest proportional increases in vital rates and subsequently also the smallest proportional increases in lambda. For chick survival in E Colorado, a negligible increase in lambda, because chick survival was high and estimated precisely, yielded a much smaller proportional increase in that vital rate $(0.05)$ relative to the other two locations. Estimated changes in lambda across sites were most variable among sites for chick and nest survival (Fig. 2).

\section{DISCUSSION}

This study provides important new insights into the relative importance of factors that affect population growth rate in the Mountain Plover. Using data from three important but widely separated breeding sites, we have shown that stochastic population growth rate in general is most sensitive to proportional changes in adult survival (Table 3). Correlations between population growth rate and the vital rates were lowest for nest and juvenile survival, which suggests that future population growth in this species is on average most limited by other vital rates such as low mean chick survival (Table 4). We reiterate that we did not formally model interactions between each site, which could affect the interpretation of our results with respect to movements and survival. Below, we discuss these findings in the context of Mountain Plover conservation and in the broader context of shorebird conservation.

Results from this study are similar to those from a previous population matrix analysis of the Mountain Plover (Dinsmore 2003) although we found a greater emphasis on mean adult survival and a much lower emphasis on mean first-year reproduction in this study. On average, Mountain Plover population growth at each site was most influenced by proportional changes in adult survival, which was not surprising and is a common finding in studies of long-lived birds (Beissinger 1995, Franklin et al. 2000, Calvert et al. 2006). The life history strategy of the plover is such that they first breed at age 1 (Skrade and Dinsmore 2010), breed every year thereafter, and have high adult survival. Thus, they have repeated reproductive attempts throughout their life and each individual breeding attempt is less important, as evidenced by the comparatively low chick survival rates. The plover's atypical breeding system that includes multiple clutches per pair (Graul 1973) may result in greater than normal reproductive potential relative to other shorebirds. This species can therefore produce $>1$ brood per pair 
Table 3. Mean vital rates and an estimate of population growth rate calculated at those means $\left(\lambda_{\text {Mean }}\right)$ for Mountain Plovers breeding in Montana, eastern Colorado, and the South Park region of Colorado.

\begin{tabular}{lllllll}
\hline \hline \multirow{2}{*}{ Site } & \multicolumn{7}{c}{ Mean vital rates } \\
\cline { 2 - 7 } & $S_{\text {Chick }}$ & $S_{\text {Juvenile }}$ & $S_{\text {Nest }}$ & \# eggs & $S_{\text {Adult }}$ & $\lambda_{\text {Mean }}$ \\
\hline Montana & 0.2068 & 0.6303 & 0.4608 & 2.7310 & 0.8706 & 1.0513 \\
E Colorado & 0.6719 & 0.6302 & 0.3600 & 2.7615 & 0.8703 & 1.3797 \\
South Park & 0.2045 & 0.6295 & 0.6306 & 2.6942 & 0.8697 & 1.1181 \\
\hline
\end{tabular}

annually, which could affect population growth rate differently than in other shorebirds. Nests are thus of lesser value in this species, as confirmed by our analyses, while later life history stages, i.e., chick and adult survival, are of greater importance. Indeed, the variation observed in estimates for chick survival suggests that the potential for the highest proportional increases in vital rates occurs for chick survival. Accordingly, the highest proportional increases in lambda are realized by maintaining the highest chick survival rates, at least for those sites where chick survival was most variable (Fig. 2, Table 4). For southeastern Colorado, where chick survival was more precisely estimated, the largest potential gain in population growth rate derives from maximizing the adult survival rate (Table 4).

Our modeling results do not confirm earlier reports of Mountain Plover population declines attributed to a host of factors, most notably poor nest survival. Mountain Plover nest survival is comparable to that of other ground-nesting shorebirds in the Great Plains, including the Piping Plover (Harris et al. 2005), but greater than that of another grasslandnesting shorebird, the Long-billed Curlew (Clarke 2006). Nest survival does not currently appear to be a limiting factor to population growth in this species on the basis of our modeling. The Mountain Plover experiences increased nest survival compared to many other shorebirds, and multiple nests per pair resulting from their atypical mating system (Graul 1973), which collectively suggests that nests per se are not limiting their population growth. Proponents of nest enhancement practices might argue that they are beneficial to the plover (Lock and VerCauteren $2008)$. However, the small (10-20\%) gains in nest survival do not translate into population gains through recruitment because of low chick survival. Conversely, chick survival in Montana was low (Dinsmore and Knopf 2005) and predictions about survival from hatch to age 1 in Montana also produced unusually low estimates (Dinsmore 2008). Jointly, this suggests that chick survival may be an important factor limiting population growth in Montana, and this was reaffirmed by the results of our elasticity analyses. This life history stage is often difficult to measure in birds, especially for precocial species, because of the need to use small radio transmitters on mobile young. The data used in our model came from two detailed studies of plover chick survival that used radio telemetry (Dinsmore and Knopf 2005, Dreitz 2009). Migration survival has not been measured and should be a focus of future studies of the plover. Our estimates of annual survival span the interval between successive breeding seasons; there are no empirical estimates for survival rates during spring and fall migration periods. Within-season survival rates during winter (Knopf and Rupert 1995) and the nesting season (Knopf and Rupert 1996, Dinsmore and Knopf 2005) are close to 1.0 and suggest that it is important to learn more about survival during migration. 
Table 4. Estimates of population growth rate at the maximum value for each vital rate for Mountain Plovers breeding in Montana, eastern Colorado, and the South Park region of Colorado. The coefficient of determination $\left(\mathrm{r}^{2}\right)$ between lambda and each vital rate is given in parentheses.

\begin{tabular}{lccccc}
\hline \hline & \multicolumn{5}{c}{ Vital rate } \\
\cline { 2 - 6 } Site & $S_{\text {Chick }}$ & $S_{\text {Juvenile }}$ & $S_{\text {Nest }}$ & \# eggs & $S_{\text {Adult }}$ \\
\hline Montana & $1.3972(0.42)$ & $1.0534(0.00)$ & $1.1849(0.08)$ & $1.0705(0.18)$ & $1.1613(0.30)$ \\
E Colorado & $1.4146(0.01)$ & $1.3882(0.00)$ & $1.4476(0.03)$ & $1.4330(0.44)$ & $1.4918(0.24)$ \\
South Park & $1.5628(0.37)$ & $1.1198(0.00)$ & $1.2752(0.28)$ & $1.1481(0.13)$ & $1.2299(0.13)$ \\
\hline
\end{tabular}

\section{Conservation implications}

The Mountain Plover is a patchily distributed endemic breeding bird of the North American Great Plains and its imperiled status is often attributed to widespread habitat loss and alteration on the breeding grounds (Dinsmore 2000, Knopf and Wunder 2006). Conservation measures enacted to benefit the plover include land management strategies designed to mimic historic conditions, i.e., primarily with grazing and fire (Knopf 2008), protect nests (Kerns and Hanni 2006, Lock and VerCauteren 2008), offer incentives to landowners to modify agricultural practices to minimize nest loss (Lock and VerCauteren 2008), and to protect native grazing systems such as prairie dogs (Miller et al. 1994, 2007). Our research suggests that management focused on nest sites and nest success appear tangential to conserving and growing plover populations. Instead, conserving prairie-dog landscapes holds much greater promise of securing the species (Dinsmore 2000, Dinsmore et al. 2005, Dreitz et al. 2005, Knopf 2008). The plover relies on disturbance, which is a key aspect of prairie dog ecology, and research has demonstrated possible benefits of prairie dogs to plover home range and movement during the nesting season (Dreitz et al. 2005), a correlation between local plover trends and prairie dog abundance (Dinsmore et al. 2005), and plover densities during the nesting season (Childers and Dinsmore 2008, Tipton et al. 2009).

An important implication of our study is that persistence of the plover is not greatly effected by survival rates of nests during the incubation period.
Most studies of their breeding biology have reported relatively high nest survival for a ground-nesting bird, often $>50 \%$ (Dinsmore et al. 2002). Nest survival, a component of matrix elements $f_{1}$ and $f_{2}$, was among the least important parameters influencing population growth in each of the three populations we studied. By contrast, survival of chicks, juveniles, and adults was far more important to population growth rate. Managers faced with the task of increasing local plover populations must make choices about which life history strategy to emphasize in their efforts. Current management efforts emphasize increasing nest success, often because it is easy to find nests and implement nest protection measures (Lock and VerCauteren 2008). Managing to enhance chick or adult survival is a more difficult task and might require large-scale habitat alterations to enhance food resources or reduce vulnerability to predators. From a management perspective, it is probably easier to protect nests than chicks or adults, although we hope that this paper emphasizes the need to change this paradigm to a focus on life history stages other than nest success.

\section{CONCLUSION}

Our modeling results provide greater insight into demographic factors that affect population growth rate in the Mountain Plover. The finding that population growth is most sensitive to adult survival is not surprising, and is consistent with the findings of an earlier modeling exercise with this species (Dinsmore 2003) and a study of the closely related 
Fig. 2. The increase in population growth rate $(\lambda)$ when the maximum value for each vital rate is substituted for the mean vital rate for Mountain Plovers at three sites in North America.

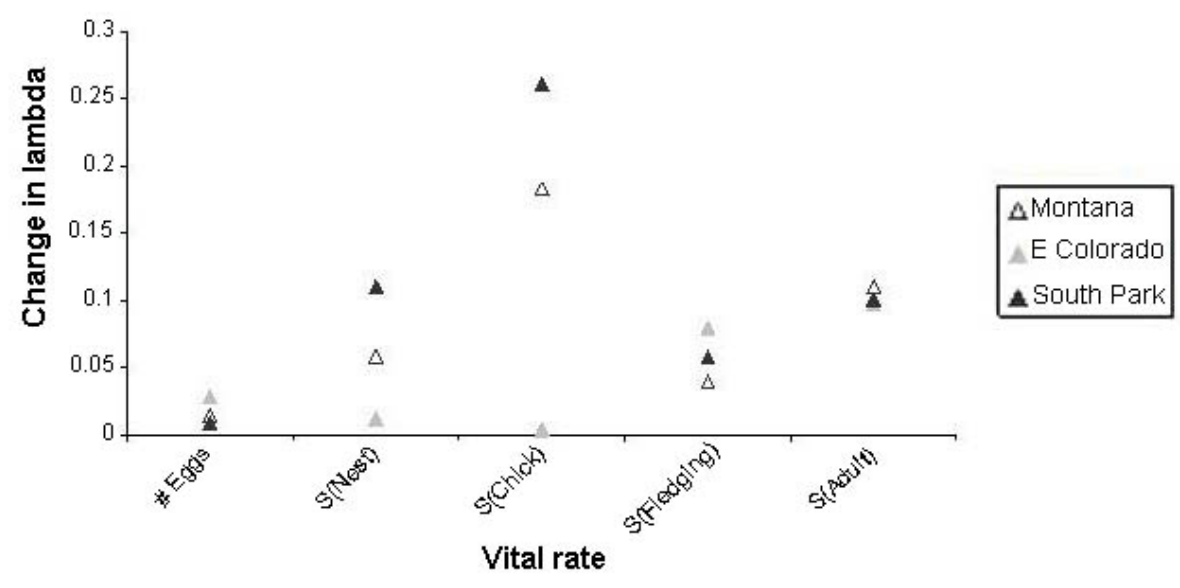

Piping Plover (Calvert et al. 2006). Furthermore, our results hint that chick survival may be limiting population growth in Montana and South Park. Lastly, nest survival provides relatively small contributions to population growth rate, especially in E Colorado and Montana. Collectively, our results suggest that a) management actions to protect nests provide lower returns than do strategies to enhance chick survival, as measured by changes in population growth rate, b) that conservation measures for the plover should emphasize measures to increase chick and possibly juvenile survival, possibly by restoring historical disturbance regimes, e.g., prairie dogs, and c) understanding factors that influence post-egg survival will be important for future conservation efforts in this species. Our modeling exercise can also serve as an example for understanding shorebird ecology in general and follows recent examples by Goss-Custard et al. $(1995 a, b)$ and Calvert et al. (2006).

Responses to this article can be read online at: http://www.ace-eco.org/vol5/iss1/art5/responses/

\section{Acknowledgments:}

We thank the many people who share our interest in the conservation of the Mountain Plover. Numerous groups have contributed financially to our longterm work with the plover, including the Bureau of Land Management, Colorado Division of Wildlife, Colorado Farm Bureau, Colorado Field Ornithologists, Denver Zoological Foundation, Fort Belknap Tribal Community, Lois Webster Fund of the Audubon Society of Great Denver, Montana Fish, Wildlife and Parks, U. S. Department of Defense (Fort Carson Military Reservation), U. S. Fish and Wildlife Service, U. S. Forest Service, and the U. S. Geological Survey(Biological Resources Division). We also thank the many people who assisted with fieldwork in our studies of the plover. C. Anderson, E. Bergman, and two anonymous reviewers provided helpful comments on earlier versions of this manuscript. 


\section{LITERATURE CITED}

Beissinger, S. R. 1995. Modeling extinction in periodic environments: Everglades water levels in Snail Kite population viability. Ecological Applications 5:618-631.

Brown, S., C. Hickey, B. Harrington, and R. Gill. 2001. The U. S. shorebird conservation plan. Second edition. Manomet Center for Conservation Sciences, Manomet, Massachusetts, USA.

Calvert, A. M., D. L. Amirault, F. Shaffer, R. Elliot, A. Hanson, J. McKnight, and P. D. Taylor. 2006. Population assessment of an endangered shorebird: the Piping Plover (Charadrius melodus melodus) in eastern Canada. Avian Conservation and Ecology 1(3): 4. [online] URL: http://www.ace-eco. org/vol1/iss3/art4/.

Caswell, H. 2001. Matrix population models. Second edition. Sinauer Associates, Sunderland, Massachusetts, USA.

Childers, T. M., and S. J. Dinsmore. 2008. Density and abundance of Mountain Plovers in northeastern Montana. The Wilson Journal of Ornithology 120:700-707.

Clarke, J. N. 2006. Reproductive ecology of Longbilled Curlews breeding in grazed landscapes of western South Dakota. Thesis. South Dakota State University, Brookings, South Dakota, USA.

Dinsmore, S. J. 2000. Mountain Plover. Pages 213-218 in R. P. Reading and B. Miller, editors. Endangered animals: a reference guide to conflicting issues. Greenwood Press, Westport, Connecticut, USA.

Dinsmore, S. J. 2001. Population biology of Mountain Plovers in southern Phillips County, Montana. Dissertation. Colorado State University, Fort Collins, Colorado, USA.

Dinsmore, S. J. 2003. Mountain Plover (Charadrius montanus): a technical conservation assessment. U. S. Forest Service, Rocky Mountain Region, Golden, Colorado, USA. [online] URL: http://www.fs.fed.us/ r2/projects/scp/assessments/mountainplover.pdf.

Dinsmore, S. J. 2008. Influence of drought on annual survival of the Mountain Plover in Montana. Condor 110:45-54.
Dinsmore, S. J., and F. L. Knopf. 2005. Differential parental care by adult Mountain Plovers, Charadrius montanus. Canadian FieldNaturalist 119:532-536.

Dinsmore, S. J., G. C. White, and F. L. Knopf. 2002. Advanced techniques for modeling avian nest survival. Ecology 83:3476-3488.

Dinsmore, S. J., G. C. White, and F. L. Knopf. 2003. Annual survival and population estimates of Mountain Plovers in southern Phillips County, Montana. Ecological Applications 13:1013-1026.

Dinsmore, S. J., G. C. White, and F. L. Knopf. 2005. Mountain Plover population responses to black-tailed prairie dogs in Montana. Journal of Wildlife Management 69:1546-1553.

Dreitz, V. J. 2005. Resolving conflicts of Mountain Plovers (Charadrius montanus) breeding on agricultural lands in Colorado. Final report. Colorado Natural Heritage Program, Fort Collins, Colorado, USA.

Dreitz, V. J. 2009. Parental behavior of a precocial species: implications for juvenile survival. Journal of Applied Ecology 46:870-878.

Dreitz, V. J., and F. L. Knopf. 2007. Mountain Plovers and the politics of research on private lands. BioScience 57:681-687.

Dreitz, V. J., M. B. Wunder, and F. L. Knopf. 2005. Movements and home ranges of Mountain Plovers raising broods in three Colorado landscapes. Wilson Bulletin 117:128-132.

Franklin, A. B., D. R. Anderson, R. J. Gutierrez, and K. P. Burnham. 2000. Climate, habitat quality, and fitness in Northern Spotted Owl populations in northwestern California. Ecological Monographs 70:539-590.

Goss-Custard, J. D., R. T. Clarke, K. B. Briggs, B. J. Ens, K.-M. Exo, C. Smit, A. J. Bientema, R. W. G. Caldow, D. C. Catt, N. A. Clark, S. E. A. Le V. Dit Durell, M. P. Harris, J. B. Hulscher, P. L. Meininger, N. Picozzi, R. Prys-Jones, U. N. Safriel, and A. D. West. 1995a. Population consequences of winter habitat loss in a migratory shorebird. I. Model predictions. Journal of Applied Ecology 32:320-336. 
Goss-Custard, J. D., R. T. Clarke, S. E. A. Le V. Dit Durell, R. W. G. Caldow, and B. J. Ens. $1995 b$. Population consequences of winter habitat loss in a migratory shorebird. II. Model predictions. Journal of Applied Ecology 32:337-351.

Graul, W. D. 1973. Adaptive aspects of the Mountain Plover social system. The Living Bird 12:69-94.

Harris, W. C., D. C. Duncan, R. J. Franken, D. T. McKinnon, and H.A. Dundas. 2005. Reproductive success of Piping Plovers at Big Quill Lake, Saskatchewan. Wilson Bulletin 117:165-171.

Kendall, W. L., K. H. Pollock, and C. Brownie. 1995. A likelihood-based approach to capturerecapture estimation of demographic parameters under the robust design. Biometrics 51:293-308.

Kerns, C., and D. Hanni. 2006. Nebraska Prairie Partners Project 2005 annual report. Annual report to Nebraska Game and Parks Commission. Rocky Mountain Bird Observatory, Brighton, Colorado, USA.

Knopf, F. L. 2008. Mountain Plover studies on the Pawnee National Grassland, 1985 - 2007. Final report. U. S. Forest Service, Fort Collins, Colorado, USA. [online] URL: http://wildlife.state.co.us/nr/rdo nlyres/CD3B7BD3-99F3-498B-863E-AABFE34C1940/0/ Knopf2008PNGPloverStudies.pdf.

Knopf, F. L., J. R. Rupert. 1995. Habits and habitats of Mountain Plovers in California. Condor 97: 743751 .

Knopf, F. L., and J. R. Rupert. 1996. Reproduction and movements of Mountain Plovers breeding in Colorado. Wilson Bulletin 108:28-35.

Knopf, F. L., and F. B. Samson. 1997. Conservation of grassland vertebrates. Pages 273-289 in F. L. Knopf and F. B. Samson, editors. Ecology and conservation of Great Plains vertebrates. SpringerVerlag, New York, New York, USA.

Knopf, F. L., and M. B. Wunder. 2006. Mountain Plover (Charadrius montanus). in A. Poole and F. Gill, editors. The Birds of North America, Number 211. The Academy of Natural Sciences,
Philadelphia, PA, and The American Ornithologists' Union, Washington D.C., USA.

Link, W. A., and J. D. Nichols. 1994. On the importance of sampling variance to investigations of temporal variation in animal population size. Oikos 69:539-544.

Lock, R., and T. VerCauteren. 2008. Mountain Plover Nest Conservation in Cultivated Fields Summary Report - 2006-2008. Technical Report \# PPR-CDOW-MOUP08-02. Rocky Mountain Bird Observatory, Brighton, Colorado, USA.

Lukacs, P. M., V. J. Dreitz, F. L. Knopf, and K. P. Burnham. 2004. Estimating survival probabilities of unmarked dependent young when detection is imperfect. Condor 106: 927-932

Mayfield, H. R. 1961. Nesting success calculated from exposure. Wilson Bulletin 73:255-261.

Mayfield, H. R. 1975. Suggestions for calculating nest success. Wilson Bulletin 87:456-466.

McDonald, D. B. and H. Caswell. 1993. Matrix methods for avian demography. Pages 280-340 in D. Power, editor. Current Ornithology, Vol. 10. Plenum Press, New York, New York, USA.

Miller, B., G. Ceballos, and R. Reading. 1994. The prairie dog and biotic diversity. Conservation Biology 8:677-681.

Miller, B., R. P. Reading, D. E. Biggins, J. K. Detling, S. K. Forrest, J. L. Hoogland, J. Javersak, S. D. Miller, J. Proctor, J. Truett, and J. W. Uresk. 2007. Prairie dogs: an ecological review and current biopolitics. Journal of Wildlife Management 71:2801-2810.

Morris, W. F. and D. F. Doak. 2002. Quantitative conservation biology: theory and practice of population viability analysis. Sinauer, Sunderland, Massachusetts, USA.

Pollock, K. H. 1982. A capture-recapture design robust to unequal probability of capture. Journal of Wildlife Management 46:757-760.

Ricklefs, R. E. 1973. Fecundity, mortality, and avian demography. Pages 366-435 in D. S. Farner, 
editor. Breeding Biology of Birds. National Academy of Sciences, Washington, D.C., USA.

Skrade, P. D. B., and S. J. Dinsmore. 2010. Dispersal patterns in the Mountain Plover (Charadrius montanus). Auk, in press.

Tipton, H. C., P. F. Doherty, Jr., and V. J. Dreitz. 2009. Abundance and density of Mountain Plover (Charadrius montanus) and burrowing owl (Athene cunicularia) in Eastern Colorado. Auk 126: 493-499.

Tuljapurkar, S. D. 1982. Population dynamics in variable environments. III. Evolutionary dynamics of r-selection. Theoretical Population Biology 21:141-165.

U. S. Department of Interior. 2000. Bitter Creek and Mountain Plover areas of critical environmental concern plan amendment and environmental assessment. MT-096-99-04. USDI, Bureau of Land Management, Glasgow Field Station, Glasgow, Montana, USA.

U. S. Department of the Interior. 2003. Endangered and Threatened Wildlife and Plants: withdrawal of the proposed rule to list the Mountain Plover as threatened. Federal Register 68 (174):53083-53101.

U. S. Forest Service. 2002. Schedule of proposed actions for NEPA analysis and public input Arapaho and Roosevelt National Forests and Pawnee National Grassland. Update for January 1 2002 through March 31, 2002. U. S. Forest Service Technical Report, Fort Collins, Colorado, USA.

White, G. C., and K. P. Burnham. 1999. Program MARK: survival estimation from populations of marked animals. Bird Study 46(Suppl.):120-139.

Williams, B. K., J. D. Nichols, and M. J. Conroy. 2001. Analysis and management of animal populations. Academic Press, New York, New York, USA.

Wunder,M.B., F.L. Knopf, and C. L. Pague. 2003. A high-elevation population of Mountain Plovers in Colorado. Condor 105:654-662. 